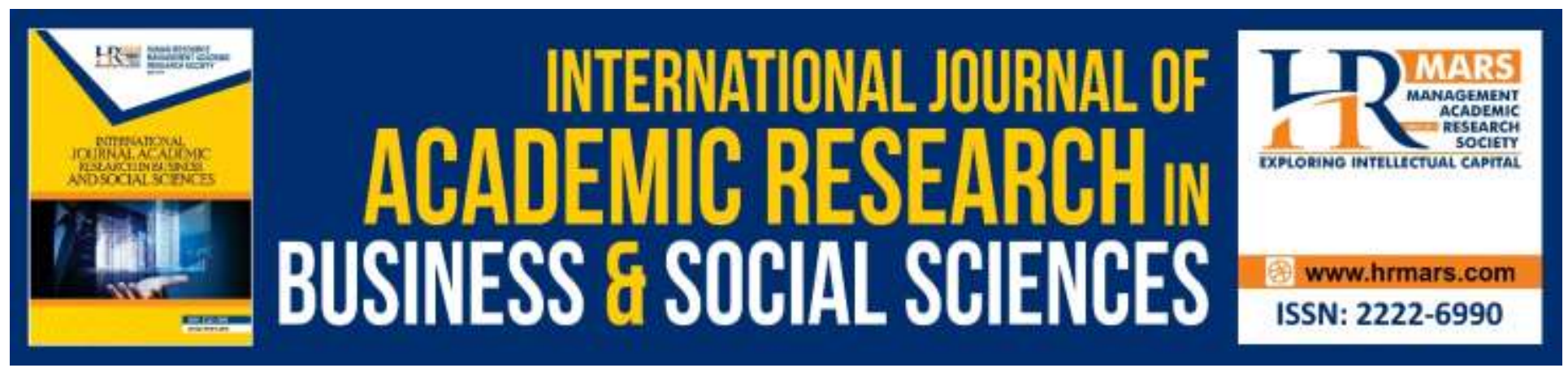

\title{
Tourists' Perspective on Ecotourism Destination Competitiveness: The Role of Tangible Components
}

Jia-Lie Ching, May-Chiun Lo, Mohamad Kadim Suaidi, Abang Azlan Mohamad \& Chee-Hua Chin

To Link this Article: http://dx.doi.org/10.6007/IJARBSS/v9-i11/6552

DOI: 10.6007/IJARBSS/v9-i11/6552

Received: 16 October 2019, Revised: 29 October 2019, Accepted: 07 November 2019

Published Online: 22 November 2019

In-Text Citation: (Ching et al, 2019)

To Cite this Article: Ching, J. L., Lo, M. C., Suaidi, M. K., Mohamad, A. A., \& Chin, C. H. (2019). Tourists' Perspective on Ecotourism Destination Competitiveness: The Role of Tangible Components. International Journal of Academic Research in Business and Social Sciences, 9(11), 335-357.

Copyright: (c) 2019 The Author(s)

Published by Human Resource Management Academic Research Society (www.hrmars.com)

This article is published under the Creative Commons Attribution (CC BY 4.0) license. Anyone may reproduce, distribute, translate and create derivative works of this article (for both commercial and non-commercial purposes), subject to full attribution to the original publication and authors. The full terms of this license may be seen at: http://creativecommons.org/licences/by/4.0/legalcode

Vol. 9, No. 11, 2019, Pg. 335 - 357

Full Terms \& Conditions of access and use can be found at http://hrmars.com/index.php/pages/detail/publication-ethics 


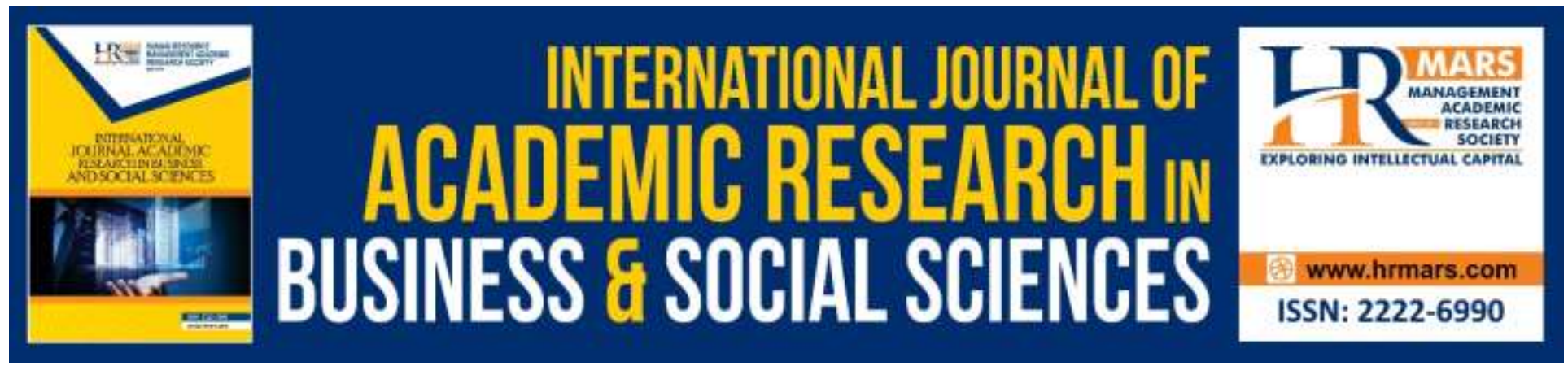

\title{
Tourists' Perspective on Ecotourism Destination Competitiveness: The Role of Tangible Components
}

\author{
${ }^{1}$ Jia-Lie Ching, ${ }^{2}$ May-Chiun Lo*, ${ }^{3}$ Mohamad Kadim Suaidi, ${ }^{4}$ Abang \\ Azlan Mohamad \& ${ }^{5}$ Chee-Hua Chin \\ ${ }^{1,2,4,5}$ Faculty of Economics and Business, Universiti Malaysia Sarawak, 94300 Kota Samarahan, \\ Sarawak, ${ }^{3}$ Chancellory, Universiti Malaysia Sarawak 94300 Kota Samarahan, Sarawak \\ Email:mclo@unimas.my
}

\begin{abstract}
In this evolving digitalized ecosphere, ecotourism is one of the important catalysts in tourism and the government has been looking forward to the opportunities in promoting the uniqueness of ecotourism attraction through Visit Malaysia 2020 campaign. Moreover, the development of ecotourism destination should be implemented in a way that maximizes destination competitiveness. In our study, we examine the relationship between the tangible components of ecotourism destination competitiveness, namely, accessibility accommodation, cultural heritage, entertainment, infrastructure, natural resources, range of activities, and special events offered with ecotourism destination competitiveness, from the demand side point of view. A total of 225 respondents comprising tourists both international and domestic tourists visited Gunung Gading National Park in Sarawak, Malaysia took part voluntarily in this study. To assess the developed model, WarpPLS (version 6.0) was applied based on path modelling and then bootstrapping to generate the standard error of the estimate and p-values. Interestingly, the findings suggested that accessibility, natural resources, infrastructure and range of activities had a significant positive impact on ecotourism destination competitiveness, whereas no significant impact found among accommodation, cultural heritage, entertainment, and special events. Implications of these findings were further discussed.

Keywords: Ecotourism, Destination Competitiveness, Tangible Aspects, National Park, Malaysia.

\section{Introduction}

Ecotourism is known as travelling to unadulterated natural areas with beautiful scenery, greenery forest, flora and fauna, and existing cultural resources from past to present (Ceballos-Lascurain, 1987; Jacobson \& Robles, 1992; Chiutsi, Mukoroverwa, Karigambe, \& Mudzengi, 2011; Coria \&
\end{abstract}


Calfucura, 2012; Mondino \& Beery, 2019). Undoubtedly, in this digitalized era of our evolving world, ecotourism is one of the important enablers in sustainable tourism industry (Das \& Syiemlieh, 2009; Cusack \& Dixon, 2006; UNEP, 2013; Anup, 2016). Past studies (Duffy, 2008; Anup, Rijal \& Sapkota, 2015) have proven that environmental protection, forest and wildlife conservation which sustaining ecotourism economic development alleviates poverty and enhance business opportunity (Hawkin, 2004; Anup, 2016). In fact, tourists have higher demand in ecotourism as taking the natural environment as priority of destination choice in travel decision (Center for Responsible Travel, 2017). Nevertheless, the United Nation World Tourism Organization (UNWTO) mentioned that it is estimated that more than 1 billion of international tourists are likely to visit various destinations by the year 2030. Subsequently, Malaysia has stepped up efforts on ecotourism towards promoting the country's uniqueness of ecotourism in the Visit Malaysia 2020 campaign. The government is looking forward to the opportunities by targeting a total of 30 million of international tourists' arrivals into Malaysia with more than RM100 billion in tourist receipt to the country in Visit Malaysia 2020 (New Straits Times, 2019; New Sarawak Tribune Online, 2019).

According to the Ministry of Tourism, Arts, Culture, Youth and Sports Sarawak (2018), the percentage of visitors who travelling to Sarawak, Malaysia has shown a decrement rate of $8.44 \%$ among domestic tourists in Year 2018 as compared to Year 2017. Among various tourists' attractions in Sarawak, National Parks of Sarawak has brought in 398,635 domestic tourists compared to 2017 , which is a decrement growth rate of $16.16 \%$ (Sarawak Forestry Corporation, 2018). Therefore, ecotourism is facing a stiff competition and encompasses a range of issues. The decline in the number tourists at national park are likely to have been caused by the ineffective management of tourism, coupled with tourists' favorable perceptions on popular destinations (Law \& Lo, 2016). Hence, the ineffective management of tourism also cause degradation of environment in order to influence the satisfaction level of tourists towards national park (Eagles, 2002; Nianyong \& Zhuge, 2001; Anup, 2016). Moreover, popular destination plays an important consideration for tourists in their selection of tourism destinations. Undeniably, visitor's experience is a determinant of destination competitiveness ensuring the profitability and sustainability of destination.

This study was conducted at Gunung Gading National Park, which is located in the state of Sarawak, Malaysia. A significant number of visitors comprising from domestic and international tourists, flock to the national park every year especially during the blooming season of the Rafflesia, the world's largest flower. The richness of natural resources and uniqueness of attractions at the national park has enable to increase the competitiveness of destination in attracting visitors to the site. At the national park, the quality of natural resources and built resources play a crucial role in enhancing tourists' satisfaction, revisit intention and destination competitiveness (Hernández, Suárez-Vega \& Santana-Jiménez, 2016; Lo, Mohamad, Chin \& Ramayah, 2017). 
In summary, this study intends to investigate eight tangible components, namely accessibility quality, accommodation quality, tourism infrastructure, entertainment, range of activities, cultural heritage, special events and natural resources and its impact on the development of ecotourism destination competitiveness from tourists' perspectives.

\section{Conceptual Background and Hypotheses Development}

\section{Competitiveness Theory and Ecotourism Destination Competitiveness}

Competitiveness Theory is applied as the underpinning theory that explains the development of ecotourism destination competitiveness. Previous studies (Mihalič, 2000; Navickas \& Malakauskaite, 2009) advocated that the Competitiveness Theory in development of destination competitiveness model is categorized into two main concepts which namely as comparative advantage (e.g. natural and artificial resources) and the competitive advantage (e.g. man-made resources). The combination of comparative advantage and competitive advantage are turned into assets of resources which gain economic benefits (Crouch \& Ritchie, 2000; Vengesayi \& Reisinger, 2013). In addition, several studies (Poon, 1993; Ritchie \& Crouch, 1999; Mihalič, 2000; Navickas \& Malakauskaite, 2009; Lo, Chin \& Law, 2019) highlighted that competitive theory are widely used to determine the destination competitiveness. Moreover, the competitiveness of ecotourism destination is influenced by the sustainability of destination. The development of long-term benefits on ecotourism is capable to achieve the sustainability and competitiveness of destination (Tseng, Lin, Lin, Wu \& Sriphon, 2019). As Competitiveness Theory indicated that the competitive advantage as one of the essential concepts that provide a theoretical and practical basis to the reciprocal relationship between the eight tangible components for the development of ecotourism destination competitiveness, namely, Gunung Gading National Park in Sarawak, Malaysia. Thus, Competitiveness Theory is adopted as the theory to govern the current study framework of the impact of tangible components that ecotourism destination competitiveness.

\section{Ecotourism Destination Competitiveness}

Destination competitiveness is defined as the ability of a destination to enhance its attractiveness in delivering quality of services (Dupeyras \& MacCallum, 2013), in providing unforgettable and unique experiences to the visitors that would be beneficial to the local communities (Ritchie \& Crouch, 2003). Subsequently, it helps to gain market shares and enhances tourists' expenditure in a sustainable way (Lubbe, Douglas, Wessels, \& Kruger, 2015; Reisinger, Michael \& Hayes, 2019). Prior studies (Dwyer \& Kim, 2003; Lee \& King, 2009) explained the necessity of development tourism destination competitiveness in attaining sustainability of the tourism industry, especially in ecotourism destinations. The tourism sustainability is a key driver of destination competitiveness to improve the superior quality services and ensure the profitability of destination (Goffi, Cucculelli \& Masiero, 2019). Besides that, previous studies (Ritchie \& Crouch, 1993; Hassan, 2000; Wilde \& Cox, 2008) have suggested several elements that play a crucial role to develop the development of tourism destination competitiveness, such as natural resources, climate/weather change, cultural and social factors and tourism infrastructure (basic service infrastructure, general infrastructure and transportation facilities). Therefore, the driving 
INTERNATIONAL JOURNAL OF ACADEMIC RESEARCH IN BUSINESS AND SOCIAL SCIENCES Vol. 9, No. 11, November, 2019, E-ISSN: 2222-6990 @ 2019 HRMARS

forces of success to develop destination competitiveness is essential for a tourism destination (Hallmann, Müller \& Feiler, 2014).

\section{Tangible Components}

Tangible components are referred to the physical aspect which can directly observe and measure whereas intangible components are defined as abstract characteristics and indirectly measurable which are related to psychological attributes (Echtner \& Ritchie, 2003; Mohamad \& Ab Ghani, 2014; Trung \& Khalifa, 2019). In this study, the tangible components are included of accessibility quality, accommodation quality, natural and cultural attractions, entertainment and activities, tourism infrastructure and special events.

\section{Accessibility Quality}

Accessibility is defined as the convenience to access the tourism destinations easily (Goffi, 2013) with the availability of transportation services (Chi \& Qu, 2008; Chin et.al, 2018). Past studies (e.g., Getz, 1997; McKercher, 1998) revealed the mode of transportation services (e.g. quality air, train, bus, or sea) are able to reach tourism destinations, particularly the ecotourism destinations. These studies also highlighted that affordability and the availability of efficient transportation system will influence tourists to make choices in selecting destinations (Dwyer \& Kim, 2003; Aguila \& Ragot, 2014). Meanwhile, the destination accessibility and infrastructure play an important role in attracting large number of tourists to visit tourism destination (Guiver \& Stanford, 2014). Previous studies (Ritchie \& Crouch, 2010; Chin et al., 2018) stated that quality of accessibility highly influence tourism destination competitiveness because it is convenient for those who are planning to travel to the destination. Furthermore, accessibility of a destination is regarded as a significant factor that enhances the level of competitiveness for a tourism destination (Goffi, 2013). The above discussions lead to the development of the following hypotheses:

H1: Accessibility quality is positively related to destination competitiveness.

\section{Accommodation Quality}

Accommodation can be referred as the hotels and motels in urban area, homestay and village stay in the context of rural area where provided a place to stay and rest (Ebrahimpour \& Haghkhah, 2010; Chin et. al, 2018). Based on the previous study by Hosseini, Bostani, and Anvari (2015) it was found that the quality of accommodation in tourists' destinations directly impacts tourists' satisfaction. In addition, an excellent quality of accommodation will gain high recommendation from positive word of mouth by existing tourists, which can help to attract new visitors (Kozak \& Rimmington, 1999; Hosseini et al., 2015). Thus, the comfortable and pleasurable accommodation services fulfil and meet tourists' expectations, which results in repeat visitations. On the other hand, past study (Hosseini et al., 2015) also pointed out that the accommodation quality in a tourism destination will influence the tourists' satisfaction and the development of 
INTERNATIONAL JOURNAL OF ACADEMIC RESEARCH IN BUSINESS AND SOCIAL SCIENCES

Vol. 9, No. 11, November, 2019, E-ISSN: 2222-6990 @ 2019 HRMARS

sustainable and competitiveness of a tourism destination (Tardivo, Scilla \& Viassone, 2014). The above discussions lead to the development of the following hypothesis:

$\mathrm{H} 2$ : Accommodation is positively related to destination competitiveness.

\section{Entertainment}

The dimension of entertainment is interpreted as activities that include live performances of music, dance, show and festivals (Hughes, 2000; Hughes \& Allen, 2008) which offered pleasurable and memorable experience to tourists (Hughes, 2000; Xu, 2010; Luo \& Lam, 2017). In tourism industry, the entertainment sector is a core resource and pulling factor that greatly impact the attractiveness of a tourism destination (Ritchie \& Crouch, 2010). Several studies (Crouch \& Ritchie, 1999; Dwyer \& Kim, 2003) posit that entertainment at a tourism destination underline the quality of the environment and uniqueness of cultural attractions. Researchers such as Song and Cheung (2010) and Ritchie and Crouch (2010) acknowledged that the availability of entertainment at a tourists' destination strengthen the destination's competitiveness. The above discussions lead to the development of the following hypothesis:

H3: Entertainment is positively related to destination competitiveness.

\section{Tourism Infrastructure}

Tourism infrastructure is defined as a physical element that is created to cater the needs of visitors (Inskeep, 1991). Researchers (Buhalis, 2000; Wilde \& Cox, 2008; Goffi, 2013) have suggested that tourism infrastructure must include the transportation infrastructure, tourism amenities, and facilitating resources. Besides, the importance of transportation infrastructure is a key determinant of the success and failure of a tourism destination (Kaul, 1985; Aref \& Gill, 2009; Ritchie \& Crouch, 2010). Furthermore, several studies (Wilde \& Cox, 2008; Aref \& Gill, 2009; Goffi, 2013) had identified transportation infrastructure as fundamental and important componenets in enhancing the competitiveness of a tourism destination. As such, the improved tourism infrastructure increased the accessibility for tourists to ease in accessing the particular tourism destination (Su \& Wall, 2009), which eventually increase the destination competitiveness (Hsueh \& Yeh, 2014). Hence, the availability of user-friendly transportation infrastructure is essential in development of tourism destination competitiveness. The above discussions lead to the development of the following hypotheses:

$\mathrm{H} 4$ : Tourism infrastructure is positively related to destination competitiveness.

\section{Range of Activities}

In a tourist destination, there are plent of activities being offered to visitors. These range of activities are referred as several attractions that include recreation, sports, and adventure which significantly accentuate the attractiveness of a tourism destination (Mazilu \& Stancioiu, 2009; Tubey \& Tubey, 2014; Parahiyanti \& Hussein, 2015). A range of activities available at a particular 
tourism destination act as a tool for destination branding (Ayikoru, 2015) which help to increase the awareness of the tourists towards that destination (Etiosa, 2012). Past studies also assured that varieties of activities available at a tourists' destination lead to the enhancement of tourism destination competitiveness (Crouch \& Ritchie, 1999; Vengesayi, 2003; Law \& Lo, 2016). Moreover, Crouch (2001) had highlighted on the importance of activities such as adventurous, recreational, and sport activities which will enhance the attractiveness of a destination and destination competitiveness (Ayikoru, 2015). Thus, a range of activities being offered at tourism destination could significantly enhance tourists' enjoyment and enable tourists to engage in the cultural activities, particularly at a rural tourism destination. The above discussions lead to the development of the following hypothesis:

H5: Range of activities is positively related to destination competitiveness.

\section{Special Events}

Special events are regarded as the core aspects that can enrich tourism destination's appeal (Özdemir Bayrak, 2011). Special events comprise of various short-term activities and functions that would attract tourists to certain destinations (Wu \& Zheng, 2014). Moreover, special events are the key determinants and motivators for tourists to select a tourism destination as a holiday choice (McKercher, Mei, \& Tse, 2006; Maneenetr \& Tran, 2014). Special events have the capability to create opportunities for tourists to explore and experience the uniqueness of a culture, heritage, and people at a destination (Lee, Lee \& Wick, 2004; Kim, Suh \& Eves, 2010; Lo et al., 2017). Festivals and events especially the food festivals are vital in tourists' decision in choosing a holiday destination (Organ, Koenig-Lewis, Palmer, \& Probert, 2015). Additionally, festivals and events are key determinants of the tourists to select a travelling destination (Dickinson, Jones, \& Leask, 2007). Thus, Wu and Zheng (2014) revealed that both festivals and events can be classified as boosting factors for a holiday spot to be appealing to the tourists. These factors are strong base to attract the tourists in order to stay competitive over other destinations. The above discussions lead to the development of the following hypothesis:

H6: Special events and festivals are positively related to destination competitiveness.

\section{Natural Resources}

Natural resources are defined as the main assets of tourism destination (Crouch and Ritchie, 1999) to gain the attention of tourists to a destination. Previous studies (Hart, 2007; Lovins, Lovins, \& Hawken, 2007) had proposed that natural resources which consist of flora and fauna, water, plants, forest, animals, soil, and stone, could be well used by people. These natural resources will certainly attract tourists to a particular destination and are therefore crucial for these natural resources to be conserved in order to retain tourism products (Fons, Fierro \& y Patiño, 2011; Sukserm, Thiengkamol, \& Thiengkamol, 2012; Chin, Lo Mohamad \& Nair, 2017). According to Jaafar and Maideen (2012), a tourism destination that are rich with natural resources could eventually increase the competitiveness advantage of that particular 
destination. The availability of quality natural resources plays a vital role in tourism industry which can influences tourists to make a choice of one destination over another (Tyrväinen, Uusitalo, Silvennoinem, \& Hasu, 2014). Those important resources help to enhance and maintain the competitiveness market. The study by Tardivo et al., (2014) and Malhotra, (2012), confirmed that the natural resources had a positive relationship with tourism destination competitiveness. The above discussions lead to the development of the following hypothesis:

H7: Natural resources is positively related to destination competitiveness.

\section{Cultural Heritage}

Cultural heritage is regarded as a mixture product of culture, such as antiquities, artworks, ethnographic materials, monuments, heritage sites and historical buildings which have intrinsic values (Lertrit, 2004; Maneenetr \& Tran, 2014). The significance of cultural heritage plays a key role in tourism destinations and it is a prominent resource (Liu, 2013; Park, 2014) to capture the tourist's attention and interest to visit the destination (Tardivo et al., 2014). Several studies (Leslie \& Sigala, 2005; Sarttatat, 2010) propounded that the conservation of cultural heritage of a tourism destination not only attract tourists but it also arises to ensure the sustainability of tourist-generated revenue. In addition, past studies confirmed the existence of a relationship between cultural and tourism destination competitiveness (Hennessey, Yun, MacDonald, \& MacEachem, 2008; Cândea, Stăncioiu, Mazilu, \& Marinescu, 2009). Researchers (Dugulan, Balaure, Popescu, \& Veghes, 2010; Ezeuduji \& Rid, 2011) highlighted that the importance of cultural heritage in determining tourism destination competitiveness. This was further supported in a study by Oye, Okafor, and Kinjir (2013) that a culture and history of a tourism destination significantly contribute to the development of tourism destination competitiveness. Thus, the attraction value of cultural heritage is a key driver to enhance the destination competitiveness and sustainability (Chin et al., 2017). The above discussions lead to the development of the following hypothesis:

H8: Cultural heritage is positively related to destination competitiveness.

\section{Methodology}

Gunung Gading National Park located at Lundu, Kuching, in the state of Sarawak, Malaysia was chosen as the research site in this study. It is one of the most popular national parks in Sarawak and is popular with its special attraction - the Rafflesia (the world's largest flower). In addition, Gunung Gading National Park also features with rainforest, jungle streams and waterfalls as well as a rich variety of flora and fauna. In this study, a quantitative approach was employed, and questionnaires were used as the research instrument for data collection. The questionnaire was made up of 69 items that were adapted from previous study and modified to adapt to the Malaysian context. The respondents are tourists who are visiting or have visited Gunung Gading National Park. By using a convenience sampling technique, a total of 232 sets questionnaires were collected and used for statistical analysis. 
First, the data was gone through a series of preliminary analysis via Statistical Package for Social Science 23.0 (SPSS). A total of 7 questionnaires were discarded due to incomplete data. Then, WarpPLS 6.0 (Kock, 2017) was utilized with 225 sets of data to assess the research model as shown in Figure 1. The data was first gone through measurement model and then structural model in PLS analysis. Measurement model contains assessment of the measures' reliability, convergent validity, and discriminant validity. After that, bootstrapping was performed to test the hypothesised relationships between constructs.

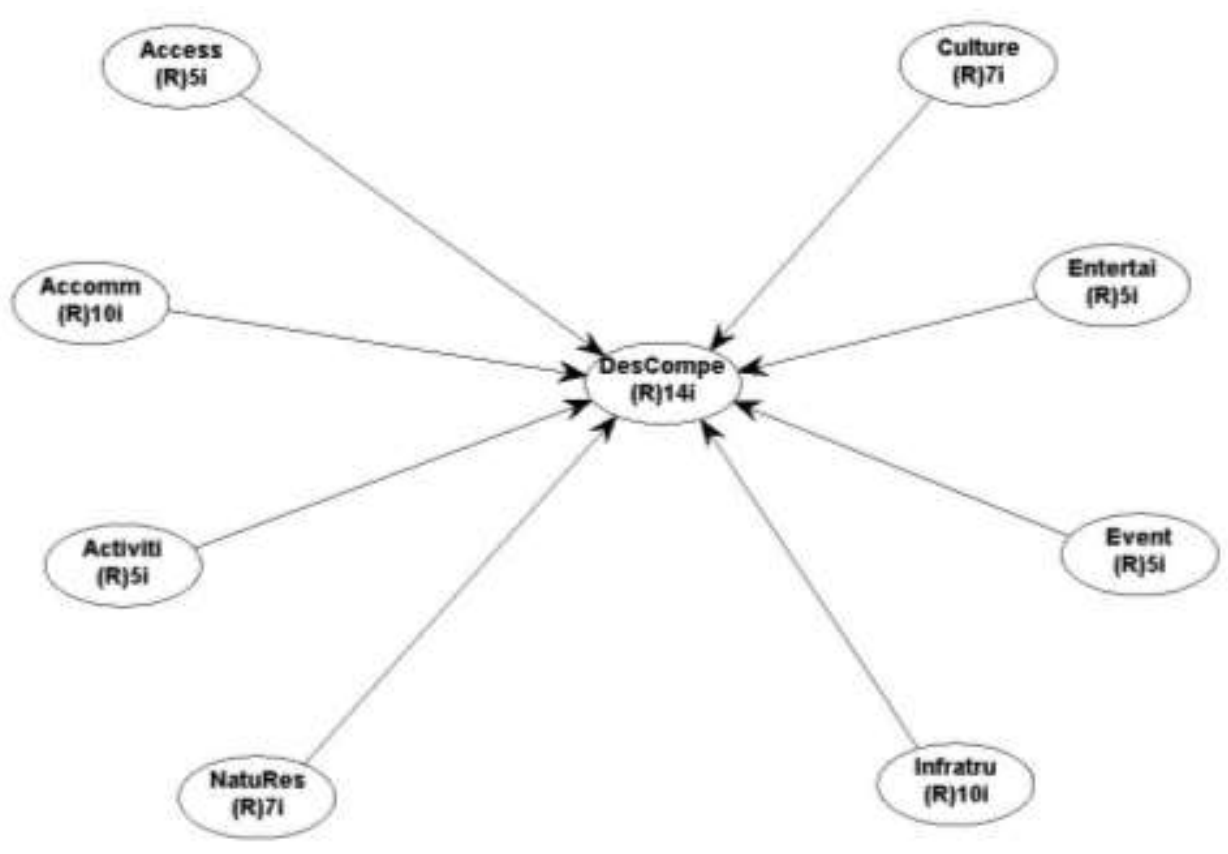

Figure 1: The research model

\section{Findings}

\section{Assessment of the Measurement Model}

Confirmatory factor analysis (CFA) was conducted to test the reliability, convergent validity as well as discriminant validity of the measures. Measurement item with outer loading value of 0.5 is considered acceptable (Chin, 1998; Hair et al., 2010). As can be seen in Table 1, all item loadings were larger than the minimum cut off point of 0.5 except "Infrastru_16" was removed due to low loading. In terms of convergent validity, as suggested by Gefen, Straub \& Boudreau (2000) all composite reliability (CR) values should exceeded the minimum cut off point of 0.7 and all average variance extracted (AVE) values should exceeded the minimum criteria of 0.5 (Bagozzi \& Yi, 1988), while the Cronbach's alpha values for all variables exceeded threshold of 0.7 (Nunally, 1978) as shown in Table 1. 
For discriminant validity, the values of AVE were square rooted and tested against the intercorrelations of the construct with other constructs in the research model (Chin, 1998, 2010; Fornell \& Larcker, 1981). As indicated in Table 2, all the square root of the AVE were greater than each of the constructs correlations. The $\mathrm{R}^{2}$ value for this model is 0.839 . Thus, it can be concluded that the measurement model was considered satisfactory with the evidence of adequate reliability, convergent validity, and discriminant validity.

Table 1: The measurement model

\begin{tabular}{|c|c|c|c|c|c|}
\hline Construct & Item & Loadings & AVE & CR & $\begin{array}{l}\text { Cronbach's } \\
\text { Alpha }\end{array}$ \\
\hline \multirow[t]{5}{*}{ Accessibility Quality } & Access_51 & 0.768 & 0.683 & 0.915 & 0.883 \\
\hline & Access_52 & 0.777 & & & \\
\hline & Access_53 & 0.893 & & & \\
\hline & Access_54 & 0.872 & & & \\
\hline & Access_55 & 0.813 & & & \\
\hline \multirow[t]{10}{*}{ Accommodation Quality } & Accomm_41 & 0.782 & 0.658 & 0.951 & 0.942 \\
\hline & Accomm_42 & 0.804 & & & \\
\hline & Accomm_43 & 0.838 & & & \\
\hline & Accomm_44 & 0.822 & & & \\
\hline & Accomm_45 & 0.823 & & & \\
\hline & Accomm_46 & 0.799 & & & \\
\hline & Accomm_47 & 0.794 & & & \\
\hline & Accomm_48 & 0.888 & & & \\
\hline & Accomm_49 & 0.751 & & & \\
\hline & Accomm_50 & 0.803 & & & \\
\hline \multirow[t]{7}{*}{ Cultural Heritage } & Culture_08 & 0.732 & 0.686 & 0.939 & 0.923 \\
\hline & Culture_09 & 0.79 & & & \\
\hline & Culture_10 & 0.829 & & & \\
\hline & Culture_11 & 0.857 & & & \\
\hline & Culture_12 & 0.856 & & & \\
\hline & Culture_13 & 0.865 & & & \\
\hline & Culture_14 & 0.861 & & & \\
\hline Destination & DestCompe_62 & 0.852 & 0.626 & 0.959 & 0.954 \\
\hline \multirow[t]{7}{*}{ Competitiveness } & DestCompe_63 & 0.858 & & & \\
\hline & DestCompe_64 & 0.802 & & & \\
\hline & DestCompe_65 & 0.774 & & & \\
\hline & DestCompe_66 & 0.765 & & & \\
\hline & DestCompe_67 & 0.829 & & & \\
\hline & DestCompe_68 & 0.753 & & & \\
\hline & DestCompe_69 & 0.804 & & & \\
\hline
\end{tabular}




\begin{tabular}{|c|c|c|c|c|c|}
\hline & DestCompe_70 & 0.800 & & & \\
\hline & DestCompe_71 & 0.796 & & & \\
\hline & DestCompe_72 & 0.737 & & & \\
\hline & DestCompe_73 & 0.695 & & & \\
\hline & DestCompe_74 & 0.815 & & & \\
\hline & DestCompe_75 & 0.777 & & & \\
\hline \multirow[t]{5}{*}{ Entertainment } & Entertain_31 & 0.912 & 0.719 & 0.926 & 0.897 \\
\hline & Entertain_32 & 0.889 & & & \\
\hline & Entertain_33 & 0.914 & & & \\
\hline & Entertain_34 & 0.873 & & & \\
\hline & Entertain_35 & 0.614 & & & \\
\hline \multirow[t]{7}{*}{ Natural Resources } & NatuRes_01 & 0.787 & 0.704 & 0.943 & 0.929 \\
\hline & NatuRes_02 & 0.732 & & & \\
\hline & NatuRes_03 & 0.836 & & & \\
\hline & NatuRes_04 & 0.847 & & & \\
\hline & NatuRes_05 & 0.856 & & & \\
\hline & NatuRes_06 & 0.905 & & & \\
\hline & NatuRes_07 & 0.897 & & & \\
\hline \multirow[t]{5}{*}{ Range of Activities } & Activities_26 & 0.778 & 0.534 & 0.851 & 0.780 \\
\hline & Activities_27 & 0.740 & & & \\
\hline & Activities_28 & 0.780 & & & \\
\hline & Activities_29 & 0.649 & & & \\
\hline & Activities_30 & 0.697 & & & \\
\hline \multirow[t]{5}{*}{ Special Events } & SpecEvent_36 & 0.852 & 0.804 & 0.953 & 0.939 \\
\hline & SpecEvent_37 & 0.900 & & & \\
\hline & SpecEvent_38 & 0.897 & & & \\
\hline & SpecEvent_39 & 0.929 & & & \\
\hline & SpecEvent_40 & 0.903 & & & \\
\hline \multirow[t]{10}{*}{ Tourism Infrastructure } & Infratru_15 & 0.653 & 0.606 & 0.939 & 0.927 \\
\hline & Infratru_17 & 0.824 & & & \\
\hline & Infratru_18 & 0.728 & & & \\
\hline & Infratru_19 & 0.759 & & & \\
\hline & Infratru_20 & 0.807 & & & \\
\hline & Infratru_21 & 0.860 & & & \\
\hline & Infratru_22 & 0.810 & & & \\
\hline & Infratru_23 & 0.759 & & & \\
\hline & Infratru_24 & 0.763 & & & \\
\hline & Infratru_25 & 0.803 & & & \\
\hline
\end{tabular}


Note:

a Composite Reliability (CR) = (square of the summation of the factor loadings) $/\{$ (square of the summation of the factor loadings) + (square of the summation of the error variances) $\}$

b Average Variance Extracted (AVE) $=$ (summation of the square of the factor loadings) $/\{($ summation of the square of the factor loadings) + (summation of the error variances) $\}$ *Item Infratru_16 was deleted due to low loading.

Table 2: Discriminant validity

\begin{tabular}{llllllllll}
\hline & $\mathbf{1}$ & $\mathbf{2}$ & $\mathbf{3}$ & $\mathbf{4}$ & $\mathbf{5}$ & $\mathbf{6}$ & $\mathbf{7}$ & $\mathbf{8}$ & $\mathbf{9}$ \\
$\mathbf{1}$ & $\mathbf{0 . 8 3 9}$ & & & & & & & & \\
$\mathbf{2}$ & 0.303 & $\mathbf{0 . 8 2 8}$ & & & & & & & \\
$\mathbf{3}$ & 0.518 & 0.366 & $\mathbf{0 . 7 7 8}$ & & & & & & \\
$\mathbf{4}$ & 0.537 & 0.516 & 0.608 & $\mathbf{0 . 7 3 0}$ & & & & & \\
$\mathbf{5}$ & 0.163 & 0.518 & 0.385 & 0.622 & $\mathbf{0 . 8 4 8}$ & & & & \\
$\mathbf{6}$ & 0.361 & 0.458 & 0.374 & 0.489 & 0.513 & $\mathbf{0 . 8 9 7}$ & & & \\
$\mathbf{7}$ & 0.619 & 0.284 & 0.805 & 0.600 & 0.267 & 0.417 & $\mathbf{0 . 8 1 1}$ & & \\
$\mathbf{8}$ & 0.558 & 0.217 & 0.601 & 0.434 & 0.139 & 0.331 & 0.738 & $\mathbf{0 . 8 2 6}$ & \\
$\mathbf{9}$ & 0.636 & 0.335 & 0.687 & 0.625 & 0.343 & 0.423 & 0.759 & 0.780 & $\mathbf{0 . 7 9 1}$ \\
\hline
\end{tabular}

Note: Diagonals represent the square root of the average variance extracted while the other entries represent the correlations.

\begin{tabular}{|llll|}
\hline 1 & Natural Resources & 6 & Special Events \\
2 & Culture Heritage & 7 & Accommodation Quality \\
3 & Tourism Infrastructure & 8 & Accessibility Quality \\
4 & Range of Activities & 9 & Destination Competitiveness \\
5 & Entertainment & & \\
\hline
\end{tabular}

\section{Assessment of the Structural Model}

Figure 2 and Table 3 present the results of the hypotheses testing. It was revealed that accessibility quality, accommodation quality, natural resources, range of activities and tourism infrastructure were found to be significantly and positively related to the destination competitiveness whereas cultural heritage, entertainment and special events are not significant predictors of destination competitiveness in this study. Hence, $\mathrm{H} 1, \mathrm{H} 2, \mathrm{H} 5, \mathrm{H} 6$ and $\mathrm{H} 8$ were supported whereas $\mathrm{H} 3, \mathrm{H} 4$ and $\mathrm{H} 7$ were rejected. The variation inflation factor (VIF) values were reported in Table 5, all the VIF values are less than 10. Thus, it is confirmed that no multicollinearity exists among the constructs (Bock, Zmud, Kim, \& Lee, 2005). As suggested by Hair, Hult, Ringle, and Sarstedt (2016) both $R^{2}$ and $Q^{2}$ should be included in explaining the predictive relevance. Hence, Blindfolding procedures were performed to obtain the $\mathrm{R}^{2}$ value. The $R^{2}$ value is 0.692 which explained $69.2 \%$ of the constructs. 


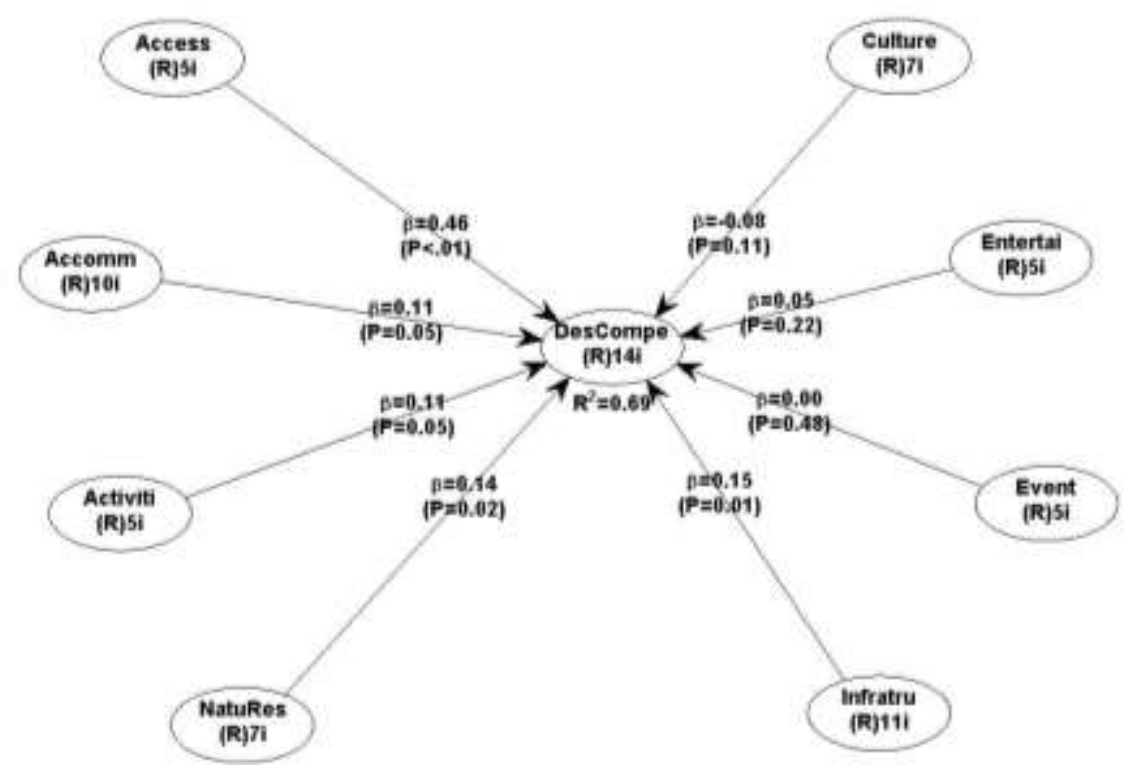

Figure 2: Research model with path coefficient and p-values

Table 3: Path coefficients and hypothesis testing

\begin{tabular}{|c|c|c|c|c|c|c|c|}
\hline Hypothesis & Relationship & Std. Beta & $\begin{array}{l}\text { Std. } \\
\text { Error }\end{array}$ & p-value & Decision & VIF & $f^{2}$ \\
\hline $\mathrm{H} 1$ & $\begin{array}{l}\text { Accessibility Quality -> } \\
\text { Destination Competitiveness }\end{array}$ & 0.458 & 0.061 & $<0.001$ & Supported & 3.153 & 0.363 \\
\hline $\mathrm{H} 2$ & $\begin{array}{l}\text { Accommodation Quality -> } \\
\text { Destination Competitiveness }\end{array}$ & 0.106 & 0.065 & 0.054 & Supported & 4.491 & 0.080 \\
\hline H3 & $\begin{array}{ll}\text { Cultural Heritage } & \text {-> } \\
\text { Destination Competitiveness }\end{array}$ & -0.083 & 0.066 & 0.104 & $\begin{array}{l}\text { Not } \\
\text { Supported }\end{array}$ & 1.596 & 0.032 \\
\hline $\mathrm{H} 4$ & $\begin{array}{l}\text { Entertainment -> Destination } \\
\text { Competitiveness }\end{array}$ & 0.050 & 0.066 & 0.227 & $\begin{array}{l}\text { Not } \\
\text { Supported }\end{array}$ & 2.256 & 0.019 \\
\hline H5 & $\begin{array}{l}\text { Natural Resources } \quad-> \\
\text { Destination Competitiveness }\end{array}$ & 0.137 & 0.065 & 0.018 & Supported & 2.029 & 0.087 \\
\hline $\mathrm{H} 6$ & $\begin{array}{l}\text { Range of Activities } \quad> \\
\text { Destination Competitiveness }\end{array}$ & 0.109 & 0.065 & 0.049 & Supported & 2.949 & 0.069 \\
\hline $\mathrm{H} 7$ & $\begin{array}{l}\text { Special Events -> Destination } \\
\text { Competitiveness }\end{array}$ & 0.004 & 0.067 & 0.479 & $\begin{array}{l}\text { Not } \\
\text { Supported }\end{array}$ & 1.662 & 0.002 \\
\hline $\mathrm{H} 8$ & $\begin{array}{l}\text { Tourism Infrastructure } \quad-> \\
\text { Destination Competitiveness }\end{array}$ & 0.153 & 0.065 & 0.009 & Supported & 3.273 & 0.110 \\
\hline
\end{tabular}

\section{Discussions}

The statistical results shown that out of eight hypotheses tested, only five direct hypotheses were supported. From the findings, accessibility quality $(\mathrm{H} 1)$, accommodation quality $(\mathrm{H} 2)$, natural resources $(\mathrm{H} 5)$, range of activities $(\mathrm{H} 6)$ and tourism infrastructure $(\mathrm{H} 8)$ were supported and found to have a positive impact on ecotourism destination competitiveness at the case of Gunung Gading National Park (GGNP). 
In the context of this study, accessibility $(\mathrm{H} 1)$ is positively related to destination competitiveness as it enabled tourists to access the destination in a convenience way (Hossain \& Islam, 2019). It comprises of the availability of local parking, convenience of local transportation, availability of travel information at the destination, helpfulness of the visitor information centre and easy access to attractions. It is not surprising that tourists found GGNP to be accessible as it took about 2 hours' drive from Kuching (capital city of Sarawak). The statistical results shown the (H2), to be positively related to destination competitiveness, which is in congruent with past study (Chin, Lo \& Law, 2017; Chin et al., 2018) The reason for the positive relationship could be visitors to GGNP are nature lovers who like to spend time with the beauty scenic nature, so they are preferred to stay overnight and enjoy the facilities available.

Natural resources $(\mathrm{H} 5)$ were noted to have a positive relationship towards destination competitiveness. The findings are corresponding to past studies which indicated the positive relationship between natural resources and destination competitiveness (Law \& Lo, 2016; Lo et al., 2017). The natural resources as an attraction of destination. Therefore, the abundance of natural resources are key factor in contributing to the development of destination competitiveness and destination sustainability. These natural attractions are considered unique especially to Eco tourists.

The finding indicated that range of activities, hypothesis 6 is seen to be an important factor to destination competitiveness. The significant positive relationship is further supported by Gupta and Singh (2019). Range of activities that are available at the GGNP which involve hiking on jungle treks and trails, biking, swimming, fishing, and eco tours. Nevertheless, for tourism infrastructure, $\mathrm{H} 8$ was found to be positively related to destination competitiveness. The infrastructure at GGNP were found to be in good condition, such as signposting within the park area, clean toilet facilities and electricity is supplied. GGNP is considered to be competitive as it was safe to visit with adequate local transportation systems, facilities and services that are ready to fulfil the visitors' needs.

In this study, three tangible components (Entertainment, Cultural heritage and Special events) were found no significance relationship with tourism destination competitiveness. Hypothesis 3 , which is cultural heritage, was not found to influence destination competitiveness. Reason for this could be due to culture-related events and activities are not a main feature at GGNP. Another possibility is because it is not located near at housing areas which consists of unique ethnic group and community. With regards to hypothesis 4, entertainment, it was found to have a low correlation with destination competitiveness, as GGNP does not offer any entertainment in the form of live performances, such as dances, traditional music or cultural shows. The same is true for hypothesis 8 , special events, as the results indicated special events to be a non-contributing dimension towards destination competitiveness. Special events refer to festivals that are held on a regular basis, which usually showcase cultural or environmental elements of the destination. However, GGNP do not have any planned regular events. 
In summary, the competitive advantage of GGNP is derived from accessibility, accommodation, natural resources, range of activities and tourism infrastructure, but not from cultural heritage, entertainment, and special events. The following section discusses the implications of the findings.

\section{Conclusions, Implications, and Recommendations}

In conclusion, the competitive advantage of GGNP is derived from factors that are more related to ecotourism destinations. The results from the findings, revealed that the relationships of variables namely, accessibility quality, accommodation quality, natural resources, range of activities and tourism infrastructure are shown to be supported to influence destination competitiveness. The theoretical and practical implication, and some limitations of this research are further discussed herewith.

This study has emphasized the importance of accessibility and accommodation quality might be the key factor to increasing the numbers of tourists at a particular destination. Subsequently, it may enhance the destination of its competitiveness and uniqueness, which lead to increase quality of the tourists' experience and enhance the value of the destination. Besides, natural resources are the main development of tourism attractions and unique selling propositions to increase the level of destination competitiveness. In the context of ecotourism, a range of activities are a significant factor that to gain attentions from tourists towards tourism destination. On the other hand, tourism infrastructure also has an important impact on destination which results in competitive advantage of destination.

From the theoretical perspective, the findings contribute to the body of knowledge of tangible components on destination competitiveness in the literature of national park such as tourism destination. The results of the present study indicated that cultural heritage, entertainment and special events do not have impact on destination competitiveness. Thus, it is believed that the study has added the value to the context on tourists' perspective towards tourism destination, especially at national park. From the practical angle, the findings of study serve as recommendations to tourism planners and policy makers and business operator to strategize and create an eco-friendly destination with valuable information for local and foreign tourists' perspective. Thus, the tourism stakeholders, tourism practitioners and local planner can utilize tangible components as a fundamental element for successful development of ecotourism destination in GGNP. Such a study is envisaged to bring practical benefit to tourism implementers and decision-makers in ecotourism industry. The essential attractors are intensely dependent on the accessibility of tourism facilities and destination resources uniqueness. Hence, the destination competitiveness and sustainability are influenced by the variety of destination core resources and supporting factors. Therefore, further examination into service quality and destination resources is strongly suggested. 
Despite the findings of the present research are subject to limitations. Generally, the sample size of this study can be further improved whereas target of sampling at different destinations and the use of different groups of target respondents such as tourism operators and lodge owners. In short, for future research, it is suggested that a further study be conducted to investigate the same areas of tourism development and their effects on the community/destination, to understand the changing of attitudes and behaviours.

\section{Acknowledgement}

The funding for this project was made possible through the research grant obtained from Sarawak Multimedia Authority and Universiti Malaysia Sarawak.

\section{References}

Aguila, G. M. \& Ragot, R. (2014). Ecotourism industry in Ilijan Batangas City, Philippines: Assessing its effects as a basis of proposed tourism development plan. Quarterly Journal of Business Studies, 1(1), 24-35.

Anup, K. C. (2016). Tourism - from empirical research towards practical application. In Butowski, L. (Eds.), Ecotourism and Its Role in Sustainable Development of Nepal (p.31-59). Nepal: INTECH.

Anup, K. C., Rijal, K., \& Sapkota, R. P. (2015). Role of ecotourism in environmental conservation and socioeconomic development in Annapurna conservation area, Nepal. International Journal of Sustainable Development \& World Ecology, 22(3), 251-258.

Aref, F. \& Gill, S. S. (2009). Rural tourism development through rural cooperatives. Nature and Science, 7(10), 68-73.

Armenski, T., Gomezelj, D. O., Djurdjev, B., Deri, L., \& Aleksandra, D. (2011). Destination competitiveness: a challenging process for Serbia. Journal of Studies and Research in Human Geography 5 (1), 19-33.

Ayikoru, M. (2015). Destination competitiveness challenges: A Ugandan perspective. Tourism Management, 50, 142-158.

Bagozzi, R. P., \& Yi, Y. (1988). On the evaluation of structural equation models. Academy of Marketing Science, 16(1), 74-94.

Bock, G. W., Zmud, R. W., Kim, Y. G., \& Lee, J. N. (2005). Behavioral intention formation in knowledge sharing: Examining the roles of extrinsic motivators, social-psychological factors, and organizational climate. MIS quarterly, 29(1), 87-111.

Buhalis, D. (2000). Marketing the Competitive Destination of the Future. Tourism Management, 21(1), 97-116.

Bredenhann, J., \& Wickens. E. (2004). Tourism routes as a tool for the economic development of rural areas - vibrant hope or impossible dream? Tourism Management, 15, 13-22.

Cândea, M., Stăncioiu, F. A., Mazilu, M., \& Marinescu, R. C. (2009). The competitiveness of the tourist destination on the future tourism market. WSEAS Transactions On Business And Economics, 6(7), 374384. 
Căprărescu, G., Daniela, L., \& Stancu, G. (2013). Quality by keeping the identity or how to obtain competitive advantage in Romanian rural tourism. International Journal of Academic Research in Economics and Management Sciences, 2(1), 1-5.

Ceballos-Lascurain, H. (1987). The future of 'ecotourism'. Mexico Journal, 1, 13-14.

Center for Responsible Travel, CERST. (2017). The case for responsible travel: Trends and statistic 2017. Retrieved from:

https://www.responsibletravel.org/docs/The\%20Case\%20for\%20Responsible\%20Tra vel\%202017_Final.pdf

Chi, C. G. Q., \& Qu, H. (2008). Examining the structural relationships of destination image, tourist satisfaction and destination loyalty: An integrated approach. Tourism management, 29(4), 624-636.

Chin, C. H., Law, F. Y., Lo, M. C., \& Ramayah, T. (2018). The impact accessibility quality and accommodation quality on tourists' satisfaction and revisit intention to rural destination in Sarawak: The moderating role of local communities' attitude. Global Business and Management Research: An International Journal, 10(2).

Chin, C. H., Lo, M. C., Mohamad, A. A., \& Nair, V. (2017). The impacts of multi-environmental constructs on tourism destination competitiveness: Local residents' perceptions. Journal of Sustainable Development, 10(3), 120-132.

Chin, W. W. (1998). The Partial least squares approach for structural equation modeling. In G. A. Marcoulides (Ed.), Modern methods for business research (pp. 295-336). NJ: Lawrence Erlbaum.

Chin, W. W. (2010). How to write up and report PLS analyses. In V. Esposito Vinzi, W. W. Chin, J. Henseler, \& H. Wang (Eds.), Handbook of partial least squares: concepts, methods and application (pp. 645-689). Germany: Springer.

Chiutsi, S., Mukoroverwa, M., Karigambe, P., \& Mudzengi, B. K. (2011). The theory and practice of ecotourism in Southern Africa. Journal of Hospitality Management and Tourism, 2(2), 14-21.

Coria, J., \& Calfucura, E. (2012). Ecotourism and the development of indigenous communities: The good, thebad, and the ugly. Ecological Economics, 73, 47-55.

Crouch, G. I., \& Ritchie, J. B. (1999). Tourism competitiveness and societal prosperity. Journal of Business Research, 44, 137-152.

Crouch, G. I., \& Ritchie, J. B. (2000). The competitive destination: A sustainability perspective. Tourism management, 21(1), 1-7.

Crouch, G. I. (2007). Modelling destination competitiveness: A survey and analysis of the impact of competitiveness attributes. Australia: CRC for Sustainable Tourism Pty Ltd.

Cusack, D., \& Dixon, L. (2006). Community-based ecotourism and sustainability. Journal of Sustainable Forestry, 22(1-2), 157-182. doi:10.1300/j091v22n01_09

Das, N., \& Syiemlieh, H. J. (2009). Ecotourism in wetland ecology. Anatolia: An International Journal of Tourism and Hospitality Research, 20(2), 445-450.

Dickinson, J., Jones, I., \& Leask, A. (2007). Event tourism; enhancing destinations and the visitor economy. International Journal of Tourism Research, 9(5), 301-394. 
Duffy, R. (2008). Neoliberalising nature: global networks and ecotourism development in Madagasgar. Journal of Sustainable Tourism, 16(3), 327-344.

Dugulan, D., Balaure, V., Popescu, I. C., \& Vegheş, C. (2010). Cultural heritage, natural resources and competitiveness of the travel and tourism industry in central and eastern European Countries. Annales Universitatis Apulensis-Series Oeconomica, 12(2).

Dupeyras, A., \& MacCallum, N. (2013). Indicators for measuring competitiveness in tourism. OECD Tourism Papers, 2013/02.

Dwyer, L., \& Kim, C. (2003). Destination competitiveness: determinants and indicators. Current Issues in Tourism, 6(5), 369-414.

Dwyer, L., Livaic, Z., \& Mellor, R. (2003). Competitiveness of Australia as a tourist destination. Journal of Hospitality and Tourism Management, 10(1), 60-79.

Eagles, P. F. J. (2002). Trends in park tourism: economics, finance and management. Journal of Sustainable Tourism, 10(2), 132-153.

Ebrahimpour, A. \& Haghkhah, A. (2010). The role of service quality in development of tourism industry. Retrieved from:

https://www.researchgate.net/profile/Azam_Haghkhah/publication/206721726_The

Role_of_Service_Quality_in_Development_of_Tourism_Industry/links/09e41505aa0f40 63dc000000. $\mathrm{d} f$ (Accessed Date: 23 NOVEMBER 2014)

Enright, M. \& Newton, J. (2005). Determinants of tourism destination competitiveness in Asia Pacific:comprehensiveness and universality. Journal of Travel Research, 43, 339-350.

Etiosa, O. (2012). The impacts of event tourism on host communities: The city of Pietarsaari (Unpublished thesis). Degree programme in Tourism, Central Ostrobothnia University of Applied Sciences, Unit for Technology and Business, Kokkola-Pietarsaari. Retrieved from: https://publications.theseus.fi/bitstre am/ handle/10024/43714/omoregie_etiosa.pdf?sequence=1

Ezeuduji, I. O., \& Rid, W. (2011). Rural tourism offer and local community participation in The Gambia. Tourismos, 6(2).

Fons, M. V. S., Fierro, J. A. M., \& y Patiño, M. G. (2011). Rural tourism: A sustainable alternative. Applied Energy, 88(2), 551-557.

Fornell, C. \& Larcker, D. F. (1981). Evaluating structural equation models with unobservable variables and measurement error. Journal of Marketing Research, 48, 39-50.

Gefen, D., Straub, D. W., \& Boudreau, M. C. (2000). Structural equation modeling and regression: Guidelines for research practice. Communications of the Association for Information Systems, 4(7), 1-78.

Getz, D. (1997). Trends and issues in sport event tourism. Tourism Recreation Research, 22(2), 61-62.

Goffi, G. (2013). A model of tourism destination competitiveness: The case of the Italian destinations of excellence (Un Modelo De Destino Turístico Competitivo: El Caso De Los Destinos Italianos De Excelencia). Anuario turismo y sociedad, 14. 
INTERNATIONAL JOURNAL OF ACADEMIC RESEARCH IN BUSINESS AND SOCIAL SCIENCES

Vol. 9, No. 11, November, 2019, E-ISSN: 2222-6990 @ 2019 HRMARS

Goffi, G., Cucculelli, M., \& Masiero, L. (2019). Fostering tourism destination competitiveness in developing countries: The role of sustainability. Journal of Cleaner Production, 209, 101115.

Gorman, C. (2005). Co-operative Marketing Structures in Rural Tourism: The Irish Case. In D. Hall, I. Kirkpatrick \& M. Mitchell (Eds.), Rural Tourism and Sustainable Business (pp. 121-137). Dublin: Channel View Publication.

Guiver, J. \& Stanford, D. (2014). Why destination visitor travel planning falls between the cracks. Journal of Destination Marketing \& Management, 3(3), 140-151.

Gupta, S., \& Singh, A. (2019). Measurement Scale of Tourism Destination competitiveness: Supply side perspectives. SCMS Journal of Indian Management, 16(1), 105-116.

Hair, J. F., Black, W. C., Babin, B. J., \& Anderson, R. E. (2010). Multivariate Data Analysis (7th ed.): Prentice Hall.

Hair, J. J. F., Hult, G. T. M., Ringle, C., \& Sarstedt, M. (2016). A primer on partial least squares structural equation modeling (PLS-SEM). Sage publications.

Hallmann, K., Müller, S., \& Feiler, S. (2014). Destination competitiveness of winter sport resorts in the Alps: how sport tourists perceive destinations?. Current Issues in Tourism, 17(4), 327-349.

Hart, S. L. (2007). Beyond Greening: Strategies for a Sustainable World. Harvard Business Review on Green Business Strategy, Harvard Business School Press.

Hassan, S. S. (2000). Determinants of market competitiveness in an environmentally sustainable tourism industry. Journal of Travel Research, 38(3), 239-245.

Hawkins, D. E. (2004). A protected areas ecotourism competitive cluster approach to catalyse biodiversity conservation and economic growth in Bulgaria. Journal of Sustainable Tourism, 12(3), 219-244.

Heath, E. (2002). Towards a model to enhance Africa's sustainable tourism competitiveness. Journal of Public Administration 37(3.1), 327-353.

Hennessey, S., Yun, D., MacDonald, R. M., \& Maceachern, M. (2008). A study of cultural tourism: the case of visitors to Prince Edward Island. In 4th World Conference for Graduate Research in Tourism, Hospitality and Leisure, Antalya, Turkey.

Hernández, J. M., Suárez-Vega, R., \& Santana-Jiménez, Y. (2016). The inter-relationship between rural and mass tourism: The case of Catalonia, Spain. Tourism Management, 54, 43-57.

Hosseini, M. R., Bostani, M. K., \& Anvari, M. R. (2015). Analysis and prioritization of factors affecting the tourists' satisfaction (Case study: in Southern Khorasan Province). IOSR Journal of Engineering, 5(7), 37-42.

Hossain, M. K., \& Islam, S. (2019). An analysis of destination attributes to enhance tourism competitiveness in Bangladesh. African Journal of Hospitality, Tourism and Leisure, 8 (2).

Hughes, H. (2000). Arts, entertainment and tourism. Oxford: Butterworth Heinemann.

Hsueh, Y. H. \& Yeh, H. M. (2014). Mapping spatial relationships among travel nodes for tourism development. International Journal of Current Research and Academic Review, 2(2), 199211. 
Hughes, H. L., \& Allen, D. (2008). Entertainment and its significance in the holiday experience at UK seaside resorts. Tourism Recreation Research, 33(2), 131-141.

Inskeep, E. (1991). Tourism planning: An integrated and sustainable development approach. New York: Van Nostrand Reinhold.

Jaafar, M., \& Maideen, S. A. (2012). Ecotourism-related products and activities, and the economic sustainability of small and medium island chalets. Tourism Management, 33(3), 683-691.

Jacobson, S. K., \& Robles, R. (1992). Ecotourism, sustainable development, and conservation education: Development of a tour guide training program in Tortuguero, Costa Rica. Environmental Management, 16(6), 701-713.

Kaul, R. N. (1985). Dynamics of tourism: A trilogy, Vol. 111. New Delhi: Transportation and Marketing.

Kim, Y. G., Suh, B. W., \& Eves, A. (2010). The relationships between food-related personality traits, satisfaction, and loyalty among visitors attending food events and festivals. International Journal of Hospitality Management, 29(2), 216-226.

Kock, N. (2017). Which is the best way to measure job performance: Self-perceptions or official supervisor evaluations? International Journal of e-Collaborations, 13(2), 1-9.

Kozak, M. \& Rimmington, M. (1999). Measuring tourist destination competitiveness: conceptualconsiderations and empirical findings. Hospitality Management, 18, 273-83.

Law, F. Y., \& Lo, M. C. (2016). Rural tourism destination competitiveness of Kubah National Park in Sarawak:Tourists' perspectives. Asian Academy of Management Journal, 21(Supp. 1), 127-148.

Lee, C. F., \& King, B. (2009). A determination of destination competitiveness for Taiwan's hot springs tourism sector using the Delphi technique. Journal of Vacation Marketing, 15(3), 243-257.

Lee, C., Lee, Y., \& Wicks, B. E. (2004). Segmentation of festival motivation by nationality and satisfaction. Tourism Management, 25(1), 61-70.

Lertrit, S. (2004). Late prehistoric and early historic archaeology in the Central Highland of Thailand: excavation at the site of Sab Champa. Antiquity, 78(299).

Leslie, D., \& Sigala, M. (2005). International cultural tourism: Management, implications and cases. Routledge.

Liu, A. (2006). Tourism in rural areas: Kedah, Malaysia. Tourism Management, 27(5), 878-89.

Liu, T. K. (2013). Re-constructing cultural heritage and imagining Wa Primitiveness in the China/Myanmar Borderlands. In Cultural heritage politics in China (pp. 161-184). Springer, New York, NY.

Lo, M. C., Chin, C. H., \& Law, F. Y. (2019). Tourists' perspectives on hard and soft services toward rural tourism destination competitiveness: Community support as a moderator. Tourism and Hospitality Research, 19(2), 139-157.

Lo, M. C., Mohamad, A. A., Songan, P., \& Yeo, A. W. (2012). Positioning rural tourism: Perspectives from the local communities. International Journal of Trade, Economics and Finance, 3(1), 59-65. Retrieved from: http://www.ijtef.org/papers/173-T00022.pdf 
Long, P. T., Perdue, R. R. \& Allen, L. (1990). Rural resident tourism perceptions and attitudes by community level of tourism. Journal of Travel Research, 28 (Winter), 3-9.

Lovins, A. B., Lovins, L. H., \& Hawken, P. (2007). A road map for natural capitalism. SERIES INTRODUCTION, 250.

Lubbe, B. A., Douglas, A., Fairer-Wessels, F., \& Kruger, E. (2015). Measuring the competitiveness of South Africa as a tourist destination. Tourism Travel and Research Association: Advancing Tourism Research Globally.

Luo, J. M., \& Lam, C. F. (2017). Entertainment tourism. Routledge.

Malhotra, A. (2012, December). Critical appraisal of aspect of attractions for tourist destination competitiveness of India and Singapore. In International Conference on Trade, Tourism and Management (pp. 21-22).

Maneenetr, T., \& Tran, T. H. (2014). Local community participation in the conservation of the Naga Fireball Festival. Mediterranean Journal of Social Sciences, 5(23), 372-379.

Mazilu, M., \& Stancioiu, F. (2009). Tourist destination competitiveness: Between desirable and imperative.Geography Series, 12, 176-188.

McCool, S. F. \& Martin, S. R. (1994). Community attachment and attitudes toward tourism development. Journal of Travel Research, 32 (winter): 29-34.

McKercher, B. (1998). The effect of market access on destination choice. Journal of Travel Research, 37(1), 3947.

McKercher, B., Mei, W. S., \& Tse, T. S. (2006). Are short duration cultural festivals tourist attractions?. Journal of Sustainable Tourism, 14(1), 55-66.

Mihalič, T. (2000). Environmental management of a tourist destination: A factor of tourism competitiveness. Tourism management, 21(1), 65-78.

Ministry of Tourism, Arts, Culture, Youth and Sports Sarawak (2017). Sarawak tourism quick facts 2017. Retrieved

from:https://mtacys.sarawak.gov.my/page-0-228-200SARAWAK-

TOURISMQUICKFACTS.html

Mohamad, M., \& Ghani, A. N. I. (2014). Comparing Destination Image and Loyalty between Firsttime and Repeat-visit Tourists. In SHS Web of Conferences (Vol. 12, p. 01047). EDP Sciences.

Mondino, E., \& Beery, T. (2019). Ecotourism as a learning tool for sustainable development. The case of Monviso Transboundary Biosphere Reserve, Italy. Journal of Ecotourism, 18(2), 107-121.

Navickas, V., \& Malakauskaitè, A. (2009). The possibilities for the identification and evaluation of tourism sector competitiveness factors. Inžinerine ekonomika, (1), 37-44.

New Sarawak Tribune Online. (2019). Make Visit Malaysia 2020 a national mission: Mahathir. Retrieved from: https://www.newsarawaktribune.com.my/make-visit-malaysia-2020-anational-mission-mahathir/

New Straits Times. (2019). Visit Malaysia 2020 targets to bring in RM100b in tourist receipts. Retrieved from: https://www.nst.com.my/business/2019/03/466912/visit-malaysia2020-targets-bringrm100btourist receipts 
Newall, L. W. (1992). The challenge of competitiveness. Business Quarterly, 56, 94-100.

Nianyong, H., \& Zhuge, R. (2001). Ecotourism in China's nature reserves: opportunities and challenges. Journal of Sustainable Tourism, 9(3), 228-242.

Nunnally, J. C. (1978). Psychometric theory. New York: McGraw-Hill.

Gomezelj, D. O., \& Mihalič, T. (2008). Destination competitiveness-Applying different models, the case of Slovenia. Tourism management, 29(2), 294-307.

Organ, K., Koenig-Lewis, N., Palmer, A., \& Probert, J. (2015). Festivals as agents for behaviour change: A study of food festival engagement and subsequent food choices. Tourism Management, 48, 84-99.

Oye, N. D., Okafor, C. I., \& Kinjir, S. (2013). Sustaining tourism destination competitiveness using ICT in developing countries. International Journal of Computer and Information Technology, 2(1), 48-56.

Ozdemir Bayrak, G. (2011). Festival motivators and consequences: a case of Efes Pilsen Blues Festival, Turkey. Anatolia, 22(3), 378-389.

Parahiyanti, C. R., \& Hussein, A. S. (2015). The Determinants of Visitor's Revisit Intention: A Lesson from ljen Car Free Day. Asia-Pacific Management and Business Application, 3(2), 74-85.

Park, H. (2014). Heritage Tourism. London: Routledge.

Perdue, R. R., Long, P. T., \& Kang, Y. S. (1995). Resident support for gambling as a tourism development strategy. Journal of Travel Research, 34(2), 3-11.

Poon, A. (1993). Tourism, Technology and Competitive Strategies. Wallingford: CAB International.

Reisinger, Y., Michael, N., \& Hayes, J. P. (2019). Destination competitiveness from a tourist perspective: A case of the United Arab Emirates. International Journal of Tourism Research, 21(2), 259-279.

Ringle, C. M., Sven, W., \& Alexander, W. (2005). SmartPLS 2.0. Retrieved from: http://www.smartpls.de.

Ritchie, J. R. B., \& Crouch, G. (1993, October). Competitiveness in International Tourism: A Framework for Understanding and Analysis. Paper presented at the 43rd Congress of Association Internationale d'Experts Scientifique de Tourisme. San Carlos de Bariloche, Argentina.

Ritchie, J. B., \& Crouch, G. I. (2003). The competitive destination: A sustainable tourism perspective. Cabi.

Ritchie, J. B. \& Crouch, G. I. (2010). A model of destination competitiveness/ sustainability: Brazilian perspectives. Revista de Administracao Publica, 44(5), 1049-1066.

Sarawak Forestry Corporation (SFC). (2018). Sarawak tourism quick facts 2018: National park visitor arrivals. Retrieved from:

https://mtacys.sarawak.gov.my/upload/file_folder/Quick\%20Fact/Quick\%20fact\%20201 8\%20New\%20Latest.pdf

Sharpley, R. (2002). Rural tourism and the challenge of tourism diversification: the case of Cyprus. Tourism Management, 23, 233-244. 
Song, H., \& Cheung, C. (2010). Attributes affecting the level of tourist satisfaction with and loyalty towards theatrical performance in China: Evidence from a qualitative study. International Journal of Tourism Research, 12(6), 665-679.

Su, B. (2011). Rural Tourism in China. Tourism Technology, 2(1), 48-56.

Su, M. M. \& Wall, G. (2009). The Qing-Tibet railway and Tibetan tourism: Travelers perspectives. Tourism Management, 30, 650657.

Sukserm, T., Thiengkamol, N., \& Thiengkamol, T. (2012). Development of the ecotourism management model for forest park. Journal of the Social Sciences, 7(1), 95-99.

Tardivo, G., Scilla, A., \& Viassone, M. (2014). How to become a benchmark sustainable tourist destination? A descriptive model. Business Systems Review, 3(2).

Trung, N. V. H., \& Khalifa, G. S. (2019). Impact of destination image factors on revisit intention of hotel's international tourists in Ba Ria-Vung Tau (BR-VT) the mediating role of positive word of mouth. International Journal on Recent Trends in Business and Tourism, 3(2), 106-115.

Tseng, M. L., Lin, C., Lin, C. W. R., Wu, K. J., \& Sriphon, T. (2019). Ecotourism development in Thailand: community participation leads to the value of attractions using linguistic preferences. Journal of Cleaner Production.

Tubey, W., \& Tubey, R. J. (2014). Resources and attractions for sports tourism in north rift region in Kenya. Journal of Economics and Sustainable Development, 5(23), 170-176.

Tyrväinen, L., Uusitalo, M., Silvennoinen, H., \& Hasu, E. (2014). Towards sustainable growth in nature-based tourism destinations: Clients' views of land use options in Finnish Lapland. Landscape and Urban Planning, 122, 1-15.

UNEP. (2013). Tourism: trends, challenges and opportunities, in green economy and trade. United Nations Environment Programme, 259-291.

Vengesayi, S. (2003, December). Conceptual model of tourism destination competitiveness and attractiveness. Paper presented at the ANZMAC 2003 Conference, Adelaide, Australia.

Vengesayi, S., \& Reisinger, Y. (2013). Tourism destination competitiveness: The impact of destination resources, support services and human factors. Journal of Tourism, 14(1), 79.

Wilde, S. J. \& Cox, C. (2008). Linking destination competitiveness and destination development: Findings from a mature Australian tourism destination. Proceedings of the Travel and Tourism Research Association (TTRA) European Chapter Conference - Competition in Tourism: Business and Destination Perspectives, Helsinki, Finland, 467-478.

Wu, S. I., \& Zheng, Y. H. (2014). The influence of tourism image and activities appeal on tourist loyalty - A study of Tainan city in Taiwan. Journal of Management and Strategy, 5(4), 121-135.

Xu, J. B. (2010). Perception of tourism products. Tourism Management, 31, 607-610. 